Vol. 12 (2003): 147-154.

\author{
Research note
}

\title{
The impact of further tariff reduction on the EU sugar sector in the forthcoming multilateral round
}

\author{
Ellen Huan-Niemi \\ MTT Agrifood Research Finland, Economic Research, Luutnantintie 13, FIN-00410 Helsinki, Finland, \\ e-mail:ellen.huan-niemi@mtt.fi
}

\begin{abstract}
This paper indicates the need for reform in the EU sugar sector due to the erosion of border protection in terms of further reduction in import tariffs for sugar. Three tariff reduction methods are assessed to project the border protection for EU sugar: Swiss formula proposed by the Cairns Group, Harbinson proposal by the World Trade Organization (WTO) and Uruguay Round formula proposed by the EU. In the assumed forthcoming multilateral round for agriculture, the EU would need to lower the support price for sugar by $67 \%$, if the Cairns Group tariff reduction method is used. However, if the Harbinson method is used, the EU would need to lower the support price for sugar by at least $35 \%$. On the contrary, the EU may avoid lowering the support price for sugar under three concurrent conditions: 1) the Uruguay Round formula is used as the reduction method in the new WTO round and the EU can use the minimum reduction rate of 15\% for sugar; 2) world sugar prices will recover in the future; and 3) both developed and developing countries are allowed to use the Special Safeguard Provisions.
\end{abstract}

Key words: tariff reduction, sugar, European Union, international trade, linear models, Swiss formula, Harbinson proposal, Uruguay Round formula, World Trade Organization

\section{Introduction}

Progress is slow in the negotiations for a new multilateral agreement under the World Trade Organization (WTO), where the agricultural sector is currently receiving special treatment. The global average rate of tariffs on agricultural products after the Uruguay Round is $62 \%$ (USDA 2001). In comparison, the global average rate of tariffs on manufactured products was over $40 \%$ in 1947 , but the average rate was less than $4 \%$ at the conclusion of the negotiations for the Uruguay Round in 1994 (Porter et al. 2001, p. 315). Thus, it is likely that forthcoming rounds of multilateral agreements under the WTO will focus on decreasing the protection and tariffs for agricultural products, especially in the developed countries.

One of the key issues is the formula for achieving reductions in agricultural tariff rates, which are acknowledged to be too high. The de- 


\section{AGRICULTURAL AND FOOD SCIENCE IN FINLAND}

\section{Huan-Niemi, E. The impact of further tariff reduction on the EU sugar sector}

bate in bringing import tariffs down is polarised between supporters of the so-called Swiss formula and the backers of a linear approach for reducing tariffs. Under the linear approach, which was adopted in the Uruguay Round, high and low tariffs are both reduced at the same percentage rate, leaving the highest tariffs still at prohibitive levels even after any percentage reduction has been made. The Swiss formula approach recognises the wide diversity in the current range of tariffs. Using a coefficient mechanism, high starting tariffs are reduced at a faster rate than lower tariffs, thus addressing the issue of tariff peaks for certain heavily protected products such as sugar.

The objective of this paper is to estimate the potential implications of tariff reductions on the EU sugar sector. Three proposals to decrease import tariffs are examined. These proposals are from the European Union (Uruguay Round formula), the Cairns Group (Swiss formula) and the WTO (Harbinson proposal formula). The need for reform (lowering the intervention price) in the EU sugar sector is indicated in the paper due to the erosion of border protection for sugar because of further reduction in import tariffs in the future multilateral round for agriculture. The EU sugar sector has avoided extensive reforms in the past decades, but may encounter far reaching reforms in year 2006.

Earlier studies have evaluated the impacts of alternative EU sugar reform policies on EU sugar production, consumption, welfare, world sugar prices and trade. Frandsen et al. (2003) have demonstrated that the impacts of different policy reform options (cut in sugar intervention price by $25 \%$ only or reduction in sugar production quotas by $13 \%$ only) would have very different effects on the EU sugar sector and the degree of market access for countries outside the EU. The results are generated by the GTAP model, which is a standard multi-regional, static computable general equilibrium model. Poonyth et al. (2000) have as well shown the impacts of reducing EU production quota for sugar alone and the combination of production quota reductions and intervention price cut by using a non-spatial partial equilibrium model (structural econometric model). Also, Roberts and Whish-Wilson (1991) and Bureau et al. (2001) have pointed out the option of reforming the EU sugar regime by allowing the production quota rights for sugar to be traded between sugar producers in the EU.

\section{Tariff reduction formulas}

Three different tariff reduction formulas are used for the projections of border protection for EU sugar (Table 1). The first formula is the Uruguay Round formula with a linear $36 \%$ on average and a minimum of $15 \%$ reduction in standard tariffs. The second formula is the Swiss formula proposed by the Cairns Group with standard tariffs

Table 1. Tariff reduction formulas used in the projections for border protection.

\footnotetext{
Uruguay Round formula

$\mathrm{t}_{1}=\left[(1-\mathrm{a}) * \mathrm{t}_{0}\right]$, where parameter $\mathrm{a}=0.36$ (on average $36 \%$ reduction in tariffs) or parameter $\mathrm{a}=0.15$ (with a minimum $15 \%$ reduction in tariffs)

Swiss formula $\mathrm{t}_{1}=\left(\mathrm{a} * \mathrm{t}_{0}\right) /\left(\mathrm{a}+\mathrm{t}_{0}\right)$, where parameter $\mathrm{a}=25$ (no individual tariff exceeds $25 \%$ )

Harbinson proposal formula $t_{1}=\left[(1-a) * t_{0}\right]$ for all agricultural tariffs greater than $90 \%$ in ad-valorem basis, where parameter $\mathrm{a}=0.60$ (on average $60 \%$ reduction in tariffs) or parameter $\mathrm{a}=0.45$ (with a minimum $45 \%$ reduction in tariffs)
}

$\mathrm{t}_{1}=$ import tariff for sugar at the end of the assumed new WTO round for agriculture

$\mathrm{t}_{0}=$ import tariff for sugar at the end of the Uruguay Round Agreement on Agriculture 
Vol. 12 (2003): 147-154.

not exceeding $25 \%$ after reduction and a $50 \%$ down payment reduction made in the first year. Finally, the third formula is the tariff reduction formula proposed by the WTO or the so-called Harbinson proposal (WTO 2003) with a linear $60 \%$ on average and a minimum of $45 \%$ reduction for tariffs greater than $90 \%$ in ad-valorem basis.

The negotiation process in the WTO under the Doha Development Agenda is assumed to be completed by January 2005. Hence, the new WTO round is assumed to begin in marketing year 2005/ 2006 and end in marketing year 2009/2010, over an assumed five-year implementation period.

The base year for further tariff reduction is assumed to be marketing year 2004/2005, which is the continuance of Uruguay Round's final bound rate for EU sugar. The linear reduction formulas of the Uruguay Round and Harbinson proposal are applied directly to the specific tariff rate for EU raw sugar in 2004/2005. However, the specific tariff rate for EU raw sugar is converted into ad-valorem equivalent for further tariff reduction under the Swiss formula. There is no perfect solution for converting a specific tariff into an ad-valorem equivalent. The price used for the conversion has a considerable impact on the value of the ad-valorem equivalent (Bureau and Salvatici 2003). The price utilised for calculating the ad-valorem equivalent tariff for EU raw sugar is the average of six years world market price for raw sugar during the Uruguay Round from 1995/1996 to 2000/2001. The advalorem equivalent tariff is the final bound tariff rate for EU raw sugar divided by the six-year average of the world market price for raw sugar:

Average world market price from 1995/1996 to 2000/2001 = EUR 200

Final bound tariff rate for EU raw sugar in 2000/ $2001=$ EUR 339

Ad-valorem equivalent tariff for EU raw sugar $=$ EUR 339/EUR $200=169.5 \%$

After the conversion, ad-valorem tariffs (after being reduced by the Swiss formula) are calculated on the basis of world market price mul- tiplied by the lowered ad-valorem tariff for the particular marketing year.

\section{World market prices}

The world sugar market is considered to be a highly distorted commodity market. World sugar prices are mostly driven by the level of stocks as a percentage of world sugar consumption and world demand for sugar. In the past years, the world market for sugar has been characterised by considerable overproduction and a rising level of stocks. The ratio of stocks as a percentage of world sugar consumption has risen from $36 \%$ in $1992 / 93$ to $49 \%$ in $2001 / 2002$. World stocks are at a high level, which has had the effect of depressing world market prices for sugar. It is reasonable to assume that world sugar prices will remain under pressure unless there are major changes in the current structure of the world demand and supply for sugar. Contrary to the results of Devadoss and Kropf (1996) generated by a non-spatial equilibrium world sugar model, agricultural trade liberalisation under the Uruguay Round did not stabilise the world sugar prices. In fact, the world price for raw sugar was higher at the beginning of the Uruguay Round than after the end of the Uruguay Round.

Sensitivity towards the fluctuation of world market prices for raw sugar (FOB Caribbean Price/New York No. 11) is considered by using both the Organisation for Economic Co-operation and Development (OECD 2003) and the Food and Agricultural Policy Research Institute (FAPRI 2003) projections of world market prices for raw sugar. Overall, the FAPRI projections are more optimistic compared to the OECD projections for the world prices of raw sugar. The world market prices are given in the form of free on board (FOB), but the projections are calculated on the basis of cost, insurance and freight. The cost per ton for insurance and freight can be found from Sugaronline. 
Huan-Niemi, E. The impact of further tariff reduction on the EU sugar sector

\section{Exchange rate movements and the Special Safeguard Provisions}

The volatility of the Euro has been high from year 2001 to 2003, moving from one Euro equals to USD 0.80 towards USD 1.20. In year 2001, the weak Euro scenario was dominant, but the strong Euro scenario was dominant in year 2003. The projections' sensitivity towards the strength of the Euro is measured by using two scenarios - a weak Euro scenario (EUR $1=$ USD 0.80) and a strong Euro scenario (EUR $1=$ USD 1.20). Under the scenario of a strong Euro (when world market prices are low), projections are made to show the additional border protection provided by the Special Safeguard Provisions for sugar (Commission Regulation No 1423/95). The safeguard duties are calculated according to the specifications given under Article 5.5 of the Uruguay Round Agreement on Agriculture. WTO members are allowed to impose additional duties automatically when import prices fall below a certain level or if import volumes rise above a certain level by invoking the Special Safeguard Provisions as a safeguard measure.

\section{EU proposal}

The EU will most probably lose its border protection for raw sugar in the assumed new WTO round if the standard tariff for EU raw sugar is further reduced by $36 \%$ for both weak and strong Euro scenarios. The import price (world market price plus tariff) for raw sugar from the world market will be lower than the intervention price for EU raw sugar (EUR 523). Under the scenario of a strong Euro, even the additional safeguard duties provided by the Special Safeguard Provisions are not enough to provide the border protection for EU raw sugar (Fig. 1). The EU sugar regime cannot sustain a $36 \%$ reduction in tariff without cutting the intervention price for sugar. Though, a $25 \%$ cut in the intervention price for raw sugar (earlier suggested by the EU Commission) will be adequate in providing the border protection for EU raw sugar, but the safeguard duties are needed under the scenario of a strong Euro.

The EU may avoid cutting the intervention price for raw sugar by choosing the minimum reduction level of $15 \%$ under the Uruguay Round formula and using the optimistic FAPRI figures

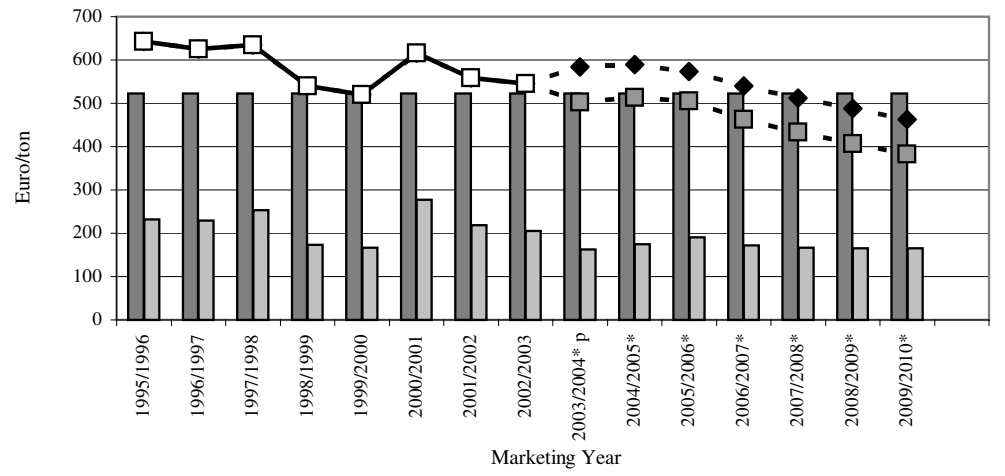

EU Support Price

World Price with Strong Euro

- - World Price with Strong Euro plus Tariff \& Additional Duties under SSG Trigger Price

- $\square$ - World Price with Strong Euro plus Tariff
Fig. 1. Uruguay Round formula and the Special Safeguard Provisions additional duties imposed The level of protection for EU raw sugar in the new WTO round under a strong Euro and after linear $36 \%$ reduction in standard tariff. *Additional duties are calculated from 2003/2004 onwards. Source: OECD 2003, USDA 2003, Commission Regulation No 1423/95, Sugaronline, author's calculations. 
Vol. 12 (2003): 147-154.

Fig. 2. Uruguay Round formula and the Special Safeguard Provisions additional duties imposed The level of protection for EU raw sugar in the new WTO round under a strong Euro and after linear $15 \%$ reduction in standard tariff. *Additional duties are calculated from 2003/2004 onwards. Source: FAPRI 2003, USDA 2003, Commission Regulation No 1423/95, Sugaronline, author's calculations.

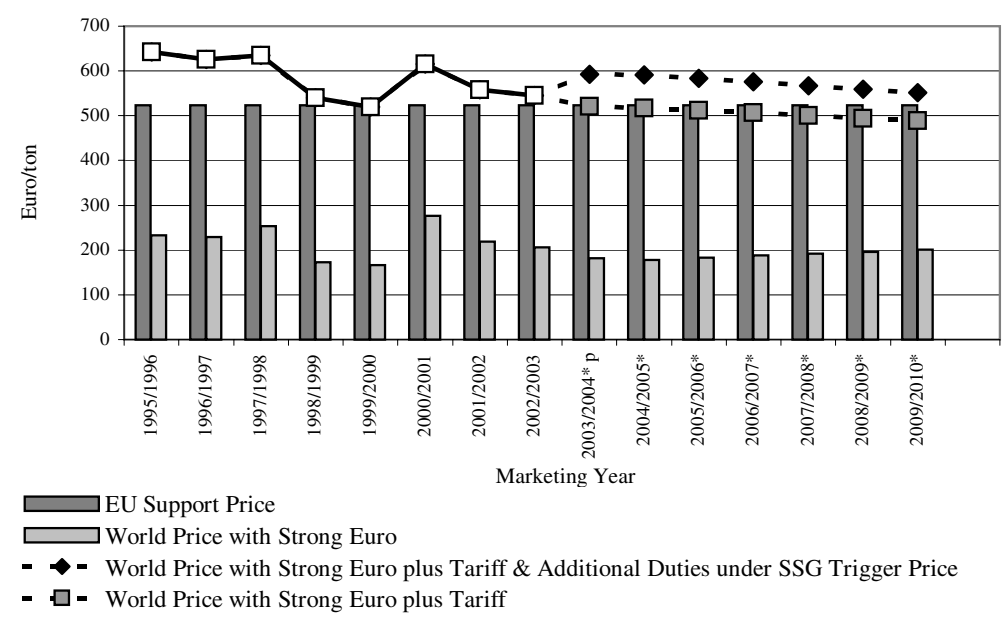

for world market prices. Furthermore, additional safeguard duties are needed under the scenario of a strong Euro (Fig. 2). As a result, three conditions are needed to avoid reform (cut in intervention price) in the EU sugar regime and maintain border protection under the assumed new WTO round: 1) the Uruguay Round formula will be accepted as the reduction method in the assumed new WTO round and the EU can use the minimum reduction rate of $15 \%$ for sugar; 2 ) world sugar prices will recover in the future (at least similar to the levels projected by FAPRI); and 3) both developed and developing countries are allowed to use the Special Safeguard Provisions.

\section{Cairns Group proposal}

The EU will even more likely lose its border protection for raw sugar in the assumed new WTO round if the standard tariff for EU raw sugar is further reduced according to the Cairns Group proposal by using the Swiss formula. Moreover, a $25 \%$ cut in the intervention price for raw sugar is not sufficient to provide border protection for both the weak and strong Euro scenarios (Fig. 3). There is a need to lower the intervention price by $67 \%$ in order to maintain border protection for EU raw sugar. Hence, the intervention price system may no longer be applicable in the EU sugar regime and most probably a safety net system would replace the intervention price system.

\section{Harbinson proposal}

The EU will probably expect to lose its border protection for raw sugar in the assumed new WTO round if the standard tariff for EU raw sugar is further reduced by $60 \%$ according to the Harbinson proposal. In order to maintain the border protection for raw sugar under this reduction rate, the intervention price needs to be lowered by $45 \%$.

The EU can also choose the minimum reduction rate of $45 \%$ under the Harbinson proposal, but the EU will still face the possibility of losing its border protection for raw sugar in the assumed new WTO round. Nonetheless, the EU will be able to sustain its border protection with a $25 \%$ cut in the intervention price for raw sugar 
Huan-Niemi, E. The impact of further tariff reduction on the EU sugar sector

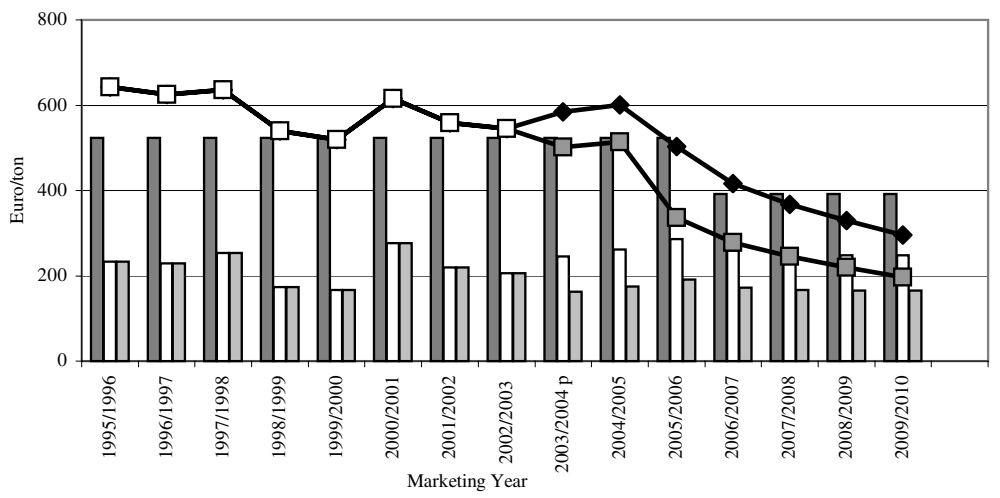

$\square$ EU Support Price

$\square$ World Price with Strong Euro

$\neg-$ World Price plus Tariff with Strong Euro

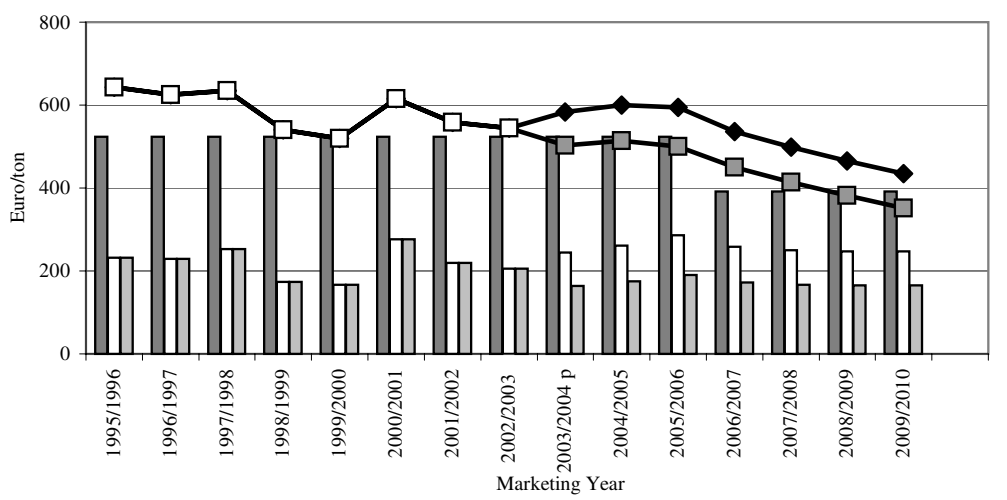

$\square$ EU Support Price

$\square$ World Price with Strong Euro

$\neg-$ World Price plus Tariff with Strong Euro $\square$ World Price with Weak Euro
World Price plus Tariff with Weak Euro

$\square$ World Price with Weak Euro

World Price plus Tariff with Weak Euro
Fig. 3. Swiss formula with $\mathrm{a}=25$ and a down payment tariff cut of $50 \%$ made in 2005/06 - The level of protection for EU raw sugar in the new WTO round after tariff reduction and a $25 \%$ cut in the intervention price for raw sugar in 2006/07. Source: OECD 2003, USDA 2003, Sugaronline, author's calculations.

Fig. 4. Harbinson proposal formula - The level of protection for EU raw sugar in the new WTO round after linear $45 \%$ reduction in standard tariff and a $25 \%$ cut in the intervention price for raw sugar in 2006/07. Source: OECD 2003, USDA 2003, Sugaronline, author's calculations. under a weak Euro scenario, but incapable of maintaining its border protection under a strong Euro scenario (Fig. 4). In this case, there is a need to lower the intervention price by $35 \%$ in order to maintain border protection for EU raw sugar.

\section{Conclusions}

The EU sugar sector is sensitive to further tariff reductions because of the huge difference between the EU support price (intervention price for raw sugar is EUR 523) and world market price for sugar (New York No. 11 is between EUR 110 to 200 per ton). The likelihood for the EU sugar sector to escape reform is small, although member governments in the WTO failed to agree on a framework of modalities for the future agriculture trade reform at the Fifth WTO Ministerial Conference held in Cancun on September 2003. The negotiations under the Doha Development Agenda are still on-going and the final agreement may not be achieved by January 2005. However, the future multilateral agreement on agriculture will eventually decrease protection for agricultural products. Thus, tariffs for 
Vol. 12 (2003): 147-154.

sugar will decline sooner or later. There is a need to reform the EU sugar sector by lowering the intervention price for sugar because of the erosion of border protection due to further reduction in import tariffs.

Besides pressures from the future multilateral agreement, the EU sugar sector is also facing legal challenges from Australia, Brazil, and Thailand in the WTO. These countries are claiming that EU exporters of $\mathrm{C}$ sugar (unsubsidised) are able to export $\mathrm{C}$ sugar at prices below their production cost due to cross-subsidy from the main A and B quota sugar of the EU sugar regime. This WTO challenge is a significant threat to the future exports of $\mathrm{C}$ sugar from the EU. Moreover, the EU's initiative to eliminate duty and quota for sugar imports from the least developed countries (LDC) is pressuring the EU to reform the sugar sector in order to avoid a major influx of sugar coming from the LDC. The EU Commission initially estimated that 2.7 million tons of sugar may enter the EU market by year 2009, but later gave a second estimation that sugar imports from the LDC would gradually increase to 900,000 tons in the medium term. Nevertheless, the EU Commission can use the endorsed safeguard measures to protect the EU sugar market from serious disturbances. The EU Commission may prevent the flood of sugar coming from the LDC after year 2009 by applying the safeguard measures enacted in the Regulation for Generalised System of Preferences and the Agreement on Safeguards under Article XIX of GATT 1994.

The EU sugar sector is facing pressures not only from the multilateral and unilateral agreements, but also from future bilateral agreements. For example, the EU-Mercosur negotiations are underway and Brazil is demanding market access to the lucrative EU sugar market. The EU Commission may extend market access for sugar in the form of expanding tariff rate quotas for Brazil or leave sugar out of the agreement (sugar is not included in the agreement between EU and South Africa).

The EU may cope with the future challenges ahead by reforming the EU sugar sector. Con- servative reforms may be the combination of a reduction in the support price and a cut in the production quotas for sugar. Radical reforms may be a drastic cut in the support price for sugar combined with the abolition of sugar production quotas or the full liberalisation of the sugar sector.

\section{References}

Bureau, J.C., Guyomard, H. \& Requillart, V. 2001. On inefficiencies in the European sugar regime. Journal of Policy Modeling 23: 659-667.

Bureau, J.C. \& Salvatici, L. 2003. WTO negotiations on market access: what we know, what we don't and what we should. In: International Conference, Agricultural policy reform and the WTO: where are we heading? 23-26 June 2003, Capri, Italy. Invited paper. Updated 9 May 2003. Cited 31 August 2003. Available on the Internet: http://www.ecostat.unical.it/ 2003agtradeconf.

Commission Regulation No 1423/95. Laying down detailed implementing rules for the import of products in the sugar sector other than molasses. Official Journal of the European Communities. The Commission of the European Communities. 23 June 1995.

Devadoss, S. \& Kropf, J. 1996. Impacts of trade liberalizations under the Uruguay Round on the world sugar market. Agricultural Economics 15: 83-96.

FAPRI 2003. World sugar. In: FAPRI 2003 U.S. and world agricultural outlook. Food and Agricultural Policy Research Institute, lowa State University and the University of Missouri-Columbia. $428 \mathrm{p}$.

Frandsen, S., Jensen, H., Wusheng, Yu \& Walter-Jørgensen, A. 2003. Reform of EU sugar policy: price cuts versus quota reductions. European Review of Agricultural Economics 30: 1-26.

OECD 2003. World sugar projections. In: OECD agricultural outlook 2003-2008. Organisation for Economic Co-operation and Development. 209 p.

Poonyth, D., Westhoff, P., Womack, A. \& Adams, G. 2000. Impacts of WTO restrictions on subsidised EU sugar exports. Agricultural Economics 22: 233-245.

Porter, R., Sauve, P., Subramanian, A. \& Zampetti, A. 2001. Efficiency, equity, legitimacy: the multilateral trading system at the millennium. Harvard University, Brookings Institution Press, Washington, D.C. $444 \mathrm{p}$.

Roberts, I.M. \& Whish-Wilson, P. 1991. Domestic and world market effects of EC sugar policies. Australian Bureau of Agricultural and Resource Economics, Canberra. Discussion Paper No. 91-1. 66 p.

Sugaronline. Independent guide to sugar prices, sugar news and sugar products and services worldwide. Updated 1 July 2002. Cited 1 December 2002. Avail- 


\title{
AGRICULTURAL AND FOOD SCIENCE IN FINLAND
}

Huan-Niemi, E. The impact of further tariff reduction on the EU sugar sector

able on the Internet: http://www.sugaronline.com/ quotes/ldp.htm.

USDA 2001. Profiles of tariffs in global agricultural markets. Economic Research Service, U.S. Department of Agriculture. $44 \mathrm{p}$.

USDA 2003. Sugar and sweetener: data tables, briefing rooms. Economic Research Service, U.S. Department of Agriculture. Updated 1 October 2002. Cited
1 December 2002. Available on the Internet: http:// www.ers.usda.gov/briefing/sugar/Data/data.htm.

WTO 2003. First draft of modalities for the further commitments (Revision - 18 March 2003), negotiations on agriculture. Committee on Agriculture, World Trade Organization. Available on the Internet: http:// www.wto.org. TN/AG/W/1/Rev.1.

\section{SELOSTUS}

\section{WT0:n kauppaneuvotteluissa esitettyjen tuontitullien alentamisvaihtoehtojen vaikutukset EU:n sokerimarkkinoihin}

\author{
Ellen Huan-Niemi \\ MTT (Maa- ja elintarviketalouden tutkimuskeskus)
}

Tutkimus paljastaa WTO:n käynnissä olevalla kauppaneuvottelukierroksella mahdollisesti sovittavien uusien kauppasääntöjen vaikutukset EU:n sokeripolitiikkaan. Tutkimuksen kohteena ovat tuontitullien alentamisvaihtoehtojen vaikutukset EU:n sokerimarkkinoihin. Tullien nopea alentaminen pakottaisi EU:n alentamaan sokerin sisämarkkinahintaa ja uudistamaan yhteistä sokeripolitiikkaa. EU:n sokeripolitiikka on erittäin herkkä tuontitullien alentamiselle, koska EU:n sisämarkkinahinta on selvästi maailmanmarkkinahintaa korkeampi.

Kehitysmaiden ja maailman suurten viejämaiden ehdotus maataloustuotteiden tullien alentamisesta 25 prosenttiin tuontihinnasta merkitsisi 67 prosentin leikkausta EU-sokerin sisämarkkinahintaan. Tämä olisi EU:lle suuri muutos, ja ilman uudistusta se mer- kitsisi sokerin tuontitulvaa EU-markkinoille. WTO:n kompromissiesitys (ns. Harbinsonin ehdotus) tuontitullien alentamisesta 45-60 prosentilla puolestaan merkitsisi vähintään 35 prosentin leikkausta EU-sokerin sisämarkkinahintaan. EU:n mahdollisuus välttyä kokonaan sokerin sisämarkkinahinnan leikkaukselta on hyvin pieni. Se on mahdollista ainoastaan kolmen seuraavan ehdon täyttyessä samanaikaisesti: 1) Uruguayn kierroksella käytössä ollutta tullinalennusmallia jatketaan uudella kierroksella, ja sokerin tuontitullia leikataan enintään 15 prosenttia, 2) sokerin maailmanmarkkinahinnat nousevat tuntuvasti tulevina vuosina ja 3) suojalausekkeen eli lisätullien käyttö poikkeusolosuhteissa sallitaan edelleen teollisuus- ja kehitysmaissa. 